\title{
PROTECTIVE EFFECTS OF SELENIUM, CALCIUM, AND MAGNESIUM AGAINST ARSENIC-INDUCED OXIDATIVE STRESS IN MALE RATS
}

\author{
Deepti SRIVASTAVA ${ }^{1}$, Ramlingam B. SUBRAMANIAN ${ }^{1}$, Datta MADAMWAR ${ }^{1}$, \\ and Swaran J. S. FLORA ${ }^{2}$ \\ BRD School of Biosciences, Sardar Patel University, Vallabh Vidyanagarl, Division of Pharmacology \\ and Toxicology, Defence Research and Development Establishment, Gwalior', India
}

Received in August 2009

Accepted in January 2010

\begin{abstract}
Inorganic arsenic is a potent carcinogen and environmental pollutant. More than one hundred million people are reported to be exposed to elevated concentrations of arsenic mainly via drinking water. Essential trace elements can affect toxicity of metals by interacting with metals at the primary site of action and can also modify the body's response to toxic metals by altering their metabolism and transport. This study investigates the effects of concomitant administration of selenium, magnesium, and calcium with arsenic on blood biochemistry and oxidative stress. Selenium was the most effective in reducing arsenic-induced inhibition of blood $\delta$-aminolevulinic acid dehydratase (ALAD) activity and liver oxidative stress. Calcium and magnesium also showed favourable effects on haematological and other biochemical parameters. Because selenium was the most effective, it should be added to chelation therapy to achieve the best protective effects against arsenic poisoning in humans.
\end{abstract}

KEY WORDS: aminolevulinic acid dehydratase, glutathione, reactive oxygen species, thiobarbituric acid reactive substances, trace elements

Arsenic (As) is a widespread environmental toxicant that may cause neuropathy, skin lesions, vascular lesions, and cancer in chronic exposure (1, $2)$. It exists in the inorganic and organic form and in different oxidation states $(-3,0,+3,+5)$. Exposure to arsenic is usually through drinking water containing naturally high amounts of inorganic arsenic. Chronic arsenic poisoning has been widely reported in the general population worldwide. Recent studies have suggested that its toxicity is owed to the production of reactive oxygen species (ROS) $(3,4)$, which include hydrogen peroxide and free radicals such as superoxide anions. Sodium arsenite has been shown to enhance haeme oxygenase production; an indicator of oxidative stress. Sodium arsenate has the ability to substitute phosphate in enzyme-catalysed reactions, where it can disrupt normal function of the enzymes (5).

Selenium is an essential component of glutathione peroxidase, an antioxidant enzyme, which plays a critical role in the body's antioxidant defence against oxidative damage by preventing the production of ROS (6). Arsenic and selenium are metalloids with similar chemical properties, but with markedly different biological effects. Selenium is known to protect against arsenic toxicity $(7,8)$. Glutathione (GSH) acts as a nucleophilic scavenger of numerous toxic compounds and their metabolites via enzymatic and chemical mechanisms and plays an important role in protecting against oxidative damage caused by ROS $(9,10)$. GSH can react non-enzymatically with ROS or can act as a substrate in GSH peroxidase-mediated 
destruction of hydroperoxides. GSH depletion can impair a cell's defence against the toxic action of many compounds and may lead to cell injury and death (10).

The aim of this study was to see the effects of selenium, magnesium, or calcium co-administered with arsenic on biochemical indicators such as haem synthesis, blood, liver, and kidney oxidative stress, liver injury, and blood and tissue arsenic concentration in male rats.

\section{MATERIALS AND METHODS}

All experiments were performed on 30 male Wistar rats, each weighing $50 \mathrm{~g}$ to $70 \mathrm{~g}$. The animals were obtained from Defense Research and Development Establishment (DRDE), Gwalior, India. All experiment protocols were approved by DRDE's ethics committee. Before the experiment, the animals were housed in stainless steel cages (six per cage) in an air-conditioned room with temperature maintained at $(25 \pm 2)^{\circ} \mathrm{C}$ and accustomed to 12 -hour light and dark cycle (light from 6:00 h to 18:00 h) for seven days. The rats received standard rat chow diet (Amrut Feeds, Pranav Agro, New Delhi, India) and water ad libitum throughout the experiment.

The rats were divided into five groups of six animals each and were receiving the following treatment for 3 weeks:

Group 1: drinking water

Group 2: $50 \mathrm{mg} \mathrm{L}^{-1}$ of sodium arsenite dissolved in drinking water

Group 3: $50 \mathrm{mg} \mathrm{L}^{-1}$ of sodium arsenite $+6.3 \mu \mathrm{mol}$ $\mathrm{L}^{-1}$ of sodium selenite by gavage $\left(2 \mathrm{~mL} \mathrm{~kg}^{-1}\right)$ once a day.

Group 4: $50 \mathrm{mg} \mathrm{L}^{-1}$ of sodium arsenite +20 mmol L-1 of magnesium sulphate by gavage $\left(2 \mathrm{~mL} \mathrm{~kg}^{-1}\right)$ once a day.

Group 5: $50 \mathrm{mg} \mathrm{L}^{-1}$ of sodium arsenite +20 mmol L-1 of calcium sulphate by gavage $\left(2 \mathrm{~mL} \mathrm{~kg}^{-1}\right)$ once a day.

The doses for arsenic and trace elements were based on previous studies $(3,11)$. All animals were anaesthetised with light ether before sacrificing. Whole blood was collected by cardiac puncture and placed in heparinized vials. The liver and the kidneys were removed, rinsed in cold saline, blotted, and weighed before biochemical tests.

The activity of blood $\delta$-aminolevulinic acid dehydratase (ALAD) was assayed according to
Berlin and Schaller (12), while white blood cells (WBC), red blood cells (RBC), haematocrit (Hct), haemoglobin $(\mathrm{Hb})$, mean cell volume (MCV), mean cell haemoglobin $(\mathrm{MCH})$, and mean cell haemoglobin concentration (MCHC) were measured using a haematology analyser (Sysmex K4500, USA). Blood GSH concentration was determined using a modified method by Jollow et al. (13). Liver and kidney GSH and GSSG (oxidised GSH) levels were determined with a spectrofluorometer (Shimadzu RF 5000, Japan) using the method of Hissin and Hilf (14). Tissue lipid peroxidation was measured using the method of Ohkawa et al. (15). ROS was determined using the method of Socci et al. (16). The activities of alanine aminotransferase (ALT) and aspartate aminotransferase (AST) in serum were determined using the method described by Reitman and Frankel (17).

Blood, liver, kidney, and brain arsenic were measured after wet acid digestion using a Microwave Digestion System (CEM, USA, model MDS-2100). Arsenic was estimated using a Hydride Vapor Generation System (Perkin Elmer model MHS-10) fitted with an atomic absorption spectrophotometer (AAS, Perkin Elmer model Analyst 100).

Data are expressed as mean \pm SE (standard error). Mean values were compared between the group using one-way ANOVA and Tukey's test. Statistical significance for differences between the unexposed and arsenic-exposed groups (with or without micronutrient) was set at $\mathrm{P}<0.05$.

\section{RESULTS}

Exposure to arsenic alone led to a significant decrease in blood ALAD activity and in GSH levels, while ROS showed a significant increase. Co-administration with Se $\left(6.3 \mu \mathrm{mol} \mathrm{L}^{-1}\right)$ showed a significant improvement in ALAD, ROS, and GSH levels, while co-administration with calcium or magnesium had only a marginal effect on these parameters (Table 1).

In the kidneys, exposure to arsenic alone led to a significant increase in ROS, but GSH, GSSG, and thiobarbituric acid reactive substances (TBARS) levels did not change significantly. Co-administration with selenium, calcium, or magnesium showed no significant effects on any of these parameters (Table 2).

Table 3 shows biochemical changes in the liver which indicate oxidative stress. ROS, TBARS and 
GSH levels significantly increased in arsenic-exposed animals, while liver GSSG increased marginally. Co-administration with selenium significantly counteracted arsenic effects, but magnesium and calcium had no effect on any of these parameters.

Exposure to arsenic alone significantly increased serum AST and ALT, while co-administration with selenium, calcium, or magnesium prevented this increase.

Tables 1-3 show arsenic concentrations in the blood, liver, and kidneys of animals exposed to arsenic alone or in combination with selenium, magnesium, or calcium. Co-administration with magnesium and selenium had a marginal beneficial effect on blood and liver arsenic concentrations, while calcium had no effect at all.

\section{DISCUSSION}

Arsenic in water is a result of natural and human activities. It is believed that nearly one hundred million people are at risk of arsenic exposure via drinking water. The arsenic issue is perhaps the most distinct in Bangladesh and West Bengal, as millions of handpumped tube wells yield drinking water with arsenic concentrations above $10 \mu \mathrm{g} \mathrm{L}^{-1}$, which is the World Health Organization drinking water guideline (18-20). In West Bengal, India, arsenic concentrations in some tube wells go as high as $3400 \mu \mathrm{g} \mathrm{L} \mathrm{L}^{-1}(21)$.

This study has investigated the effects of arsenic on biochemical parameters indicative of changes in haeme biosynthesis, liver and kidney oxidative stress, and liver damage, and has investigated the ability of

Table 1 Haematological effects of selenium, magnesium, and calcium in arsenic-exposed male rats

\begin{tabular}{|c|c|c|c|c|}
\hline Animal group & $\begin{array}{c}\text { ROS / } \\
\text { nmol mL } L^{-1}\end{array}$ & $\begin{array}{c}\text { GSH / } \\
\mathrm{mg} \mathrm{mL}^{-1}\end{array}$ & $\begin{array}{c}\text { ALAD / } \\
\text { nmol mL } \mathbf{m}^{-1}\end{array}$ & $\begin{array}{c}\text { Blood As / } \\
\text { ng dL } \mathbf{L}^{-1}\end{array}$ \\
\hline Negative control & $\begin{array}{c}0.011 \pm 0.004 \\
(0.009 \text { to } 0.013)\end{array}$ & $\begin{array}{c}6.57 \pm 0.11 \\
(6.31 \text { to } 6.71)\end{array}$ & $\begin{array}{c}29.94 \pm 1.2 \\
(25.72 \text { to } 36.12)\end{array}$ & $\begin{array}{c}0.16 \pm 0.02 \\
(0.13 \text { to } 0.19)\end{array}$ \\
\hline As & $\begin{array}{c}0.028 \pm 0.003^{\dagger} \\
(0.026 \text { to } 0.033)\end{array}$ & $\begin{array}{c}4.88 \pm 0.11^{\dagger} \\
(4.59 \text { to } 5.14)\end{array}$ & $\begin{array}{c}19.52 \pm 1.4^{\dagger} \\
(17.03 \text { to } 22.14)\end{array}$ & $\begin{array}{c}8.18 \pm 0.12^{\dagger} \\
(7.65 \text { to } 8.56)\end{array}$ \\
\hline $\mathrm{As}+\mathrm{Se}$ & $\begin{array}{c}0.018 \pm 0.001^{\ddagger} \\
(0.017 \text { to } 0.019)\end{array}$ & $\begin{array}{c}5.89 \pm 0.31^{\ddagger} \\
(4.90 \text { to } 6.18)\end{array}$ & $\begin{array}{c}26.69 \pm 1.6 \\
(22.97 \text { to } 30.23)\end{array}$ & $\begin{array}{c}5.87 \pm 0.23^{\ddagger} \\
(5.34 \text { to } 6.35)\end{array}$ \\
\hline $\mathrm{As}+\mathrm{Mg}$ & $\begin{array}{c}0.014 \pm 0.002 \\
(0.012 \text { to } 0.16)\end{array}$ & $\begin{array}{c}5.18 \pm 0.11^{\dagger} \\
(4.91 \text { to } 5.47)\end{array}$ & $\begin{array}{c}21.05 \pm 0.46^{\dagger} \\
(20.19 \text { to } 22.14)\end{array}$ & $\begin{array}{c}8.37 \pm 0.38^{\dagger} \\
\text { (8.01 to } 8.90)\end{array}$ \\
\hline $\mathrm{As}+\mathrm{Ca}$ & $\begin{array}{c}0.014 \pm 0.001 \\
(0.013 \text { to } 0.015)\end{array}$ & $\begin{array}{c}4.67 \pm 0.22^{\dagger} \\
(4.54 \text { to } 4.77)\end{array}$ & $\begin{array}{c}23.79 \pm 0.42^{\dagger} \\
(23.08 \text { to } 25.02)\end{array}$ & $\begin{array}{c}7.27 \pm 0.44^{\dagger} \\
\text { (6.45 to } 7.94)\end{array}$ \\
\hline
\end{tabular}

$R O S$ - reactive oxygen species measured in RBC in the first minute; GSH-glutathione; $A L A D$ - $\delta$-aminolevulinic acid dehydratase measured in $R B C$ in the first minute; values are expressed as mean $\pm S E(N=6)$; range values are in parenthesis $\dagger$ - significantly different from all other values; $\neq$ - significantly different from unmarked values.

Table 2 Effects of selenium, magnesium, and calcium on arsenic-induced oxidative stress parameters in rat kidney

\begin{tabular}{|c|c|c|c|c|c|}
\hline $\begin{array}{l}\text { Experimental } \\
\text { group }\end{array}$ & $\begin{array}{c}\text { TBARS / } \\
\mu g^{-1}\end{array}$ & $\begin{array}{c}\text { ROS / } \\
\text { nmol mL } \mathbf{~}^{-1}\end{array}$ & $\begin{array}{c}\text { GSH / } \\
\mu_{\mathrm{mol} \mathrm{g}}^{-1}\end{array}$ & $\begin{array}{l}\text { GSSG / } \\
\mu \mathrm{mol} \mathrm{g}^{-1}\end{array}$ & $\begin{array}{c}\text { Kidney As / } \\
n g g^{-1}\end{array}$ \\
\hline Negative control & $\begin{array}{c}4.8 \pm 0.96 \\
(3.4 \text { to } 7.5)\end{array}$ & $\begin{array}{c}1.5 \pm 0.43 \\
(0.76 \text { to } 2.3)\end{array}$ & $\begin{array}{c}3.3 \pm 0.47 \\
(2.5 \text { to } 3.6)\end{array}$ & $\begin{array}{c}2.7 \pm 0.14 \\
\text { (2.3 to } 3.0)\end{array}$ & $\begin{array}{c}0.05 \pm 0.01 \\
(0.03 \text { to } 0.06)\end{array}$ \\
\hline As & $\begin{array}{c}5.0 \pm 0.23 \\
(4.3 \text { to } 5.2)\end{array}$ & $\begin{array}{c}2.9 \pm 0.22^{\dagger} \\
(2.4 \text { to } 3.48)\end{array}$ & $\begin{array}{c}3.0 \pm 0.10 \\
(2.7 \text { to } 3.2)\end{array}$ & $\begin{array}{c}2.9 \pm 0.11 \\
(2.4 \text { to } 3.5)\end{array}$ & $\begin{array}{c}1.19 \pm 0.34^{\dagger} \\
(0.64 \text { to } 1.65)\end{array}$ \\
\hline $\mathrm{As}+\mathrm{Se}$ & $\begin{array}{c}4.2 \pm 0.68 \\
(2.6 \text { to } 5.4)\end{array}$ & $\begin{array}{c}2.9 \pm 0.63^{\dagger} \\
(1.5 \text { to } 4.1)\end{array}$ & $\begin{array}{c}3.4 \pm 0.47 \\
(3.0 \text { to } 3.8)\end{array}$ & $\begin{array}{c}2.8 \pm 0.11 \\
(2.5 \text { to } 3.0)\end{array}$ & $\begin{array}{c}1.15 \pm 0.03^{\dagger} \\
\text { (1.10 to } 1.21)\end{array}$ \\
\hline $\mathrm{As}+\mathrm{Mg}$ & $\begin{array}{c}4.1 \pm 0.34 \\
(3.4 \text { to } 5.1)\end{array}$ & $\begin{array}{c}4.1 \pm 0.34^{\dagger} \\
(3.2 \text { to } 4.9)\end{array}$ & $\begin{array}{c}3.9 \pm 0.16 \\
(3.6 \text { to } 4.2)\end{array}$ & $\begin{array}{c}2.7 \pm 0.18 \\
\text { (2.5 to } 2.9)\end{array}$ & $\begin{array}{c}1.33 \pm 0.13^{\dagger} \\
(1.01 \text { to } 1.39)\end{array}$ \\
\hline $\mathrm{As}+\mathrm{Ca}$ & $\begin{array}{c}7.3 \pm 1.40 \\
\text { (5.0 to } 11.35)\end{array}$ & $\begin{array}{c}2.9 \pm 0.21^{\dagger} \\
(2.3 \text { to } 3.2)\end{array}$ & $\begin{array}{c}2.8 \pm 0.55 \\
\text { (2.7 to } 2.9) \\
\end{array}$ & $\begin{array}{c}2.8 \pm 0.14 \\
(2.6 \text { to } 3.1)\end{array}$ & $\begin{array}{c}1.28 \pm 0.15^{\dagger} \\
\text { (1.10 to } 1.48)\end{array}$ \\
\hline
\end{tabular}

$T B A R S$ - thiobarbituric acid reactive substances; ROS - reactive oxygen species measured in $R B C$ in the first minute; GSH and GSSG - reduced and oxidised glutathione; values are expressed as mean $\pm S E(N=6)$; range values are in parenthesis $\dagger$ - significantly different from all other values; + - significantly different from unmarked values 
Table 3 Effects of selenium, magnesium, and calcium on arsenic-induced oxidative stress in rat liver

\begin{tabular}{|c|c|c|c|c|c|c|c|}
\hline $\begin{array}{l}\text { Experimental } \\
\text { group }\end{array}$ & $\begin{array}{c}\text { TBARS / } \\
\mu g^{-1} \\
\end{array}$ & $\begin{array}{c}\mathrm{ROS} / \\
\mathrm{nmol} \mathrm{mL^{-1 }} \\
\end{array}$ & $\begin{array}{c}\text { GSH / } \\
\mu_{\mathrm{mol} \mathrm{g}}^{-1}\end{array}$ & $\begin{array}{l}\text { GSSG / } \\
\mu_{\mathrm{mol} \mathrm{g}}{ }^{-1}\end{array}$ & $\begin{array}{c}\text { AST / } \\
\text { nmol mg }^{-1}\end{array}$ & $\begin{array}{c}\text { ALT / } \\
\text { nmol mg }^{-1}\end{array}$ & $\begin{array}{c}\text { Liver As / } \\
\text { ng g }^{-1} \\
\end{array}$ \\
\hline $\begin{array}{l}\text { Negative } \\
\text { control }\end{array}$ & $\begin{array}{c}4.6 \pm 0.47 \\
\text { (3.6 to } 5.6)\end{array}$ & $\begin{array}{c}1.7 \pm 0.13 \\
(1.6 \text { to } 2.3)\end{array}$ & $\begin{array}{c}5.9 \pm 0.10 \\
(5.6 \text { to } 6.1)\end{array}$ & $\begin{array}{c}4.3 \pm 0.17 \\
(3.8 \text { to } 4.6)\end{array}$ & $\begin{array}{c}10.9 \pm 0.18 \\
(8.6 \text { to } 11.1)\end{array}$ & $\begin{array}{c}10.87 \pm 0.12 \\
(10.1 \text { to } \\
11.4)\end{array}$ & $\begin{array}{c}0.1 \pm 0.04 \\
(0.5 \text { to } 1.4)\end{array}$ \\
\hline As & $\begin{array}{c}6.3 \pm 0.90^{\dagger} \\
(4.4 \text { to } 7.8)\end{array}$ & $\begin{array}{c}2.9 \pm 0.22^{\dagger} \\
\text { (1.9 to } 3.8)\end{array}$ & $\begin{array}{c}3.9 \pm 0.16^{\dagger} \\
(3.7 \text { to } 4.3)\end{array}$ & $\begin{array}{c}5.1 \pm 0.32 \\
(4.6 \text { to } 6.5)\end{array}$ & $\begin{array}{c}16.1 \pm 1.08^{\dagger} \\
(12.8 \text { to } \\
19.6)\end{array}$ & $\begin{array}{c}19.86 \pm 0.83^{\dagger} \\
(15.9 \text { to } \\
22.5)^{-}\end{array}$ & $\begin{array}{c}3.3 \pm 0.11^{\dagger} \\
(2.5 \text { to } 3.9)\end{array}$ \\
\hline $\mathrm{As}+\mathrm{Se}$ & $\begin{array}{c}4.7 \pm 0.48 \\
(3.5 \text { to } 5.8)\end{array}$ & $\begin{array}{c}1.8 \pm 0.13 \\
(1.5 \text { to } 2.1)\end{array}$ & $\begin{array}{c}5.1 \pm 0.30 \\
(4.7 \text { to } 6.0)\end{array}$ & $\begin{array}{c}4.7 \pm 0.40 \\
\text { (3.8 to } 5.4)\end{array}$ & $\begin{array}{c}12.0 \pm 0.38^{ \pm} \\
(10.8 \text { to } \\
13.7)\end{array}$ & $\begin{array}{c}13.14 \pm 0.43^{*} \\
(11.4 \text { to } \\
15.1)\end{array}$ & $\begin{array}{c}2.1 \pm 0.18 \\
(1.7 \text { to } 2.4)\end{array}$ \\
\hline $\mathrm{As}+\mathrm{Mg}$ & $\begin{array}{c}6.0 \pm 0.23^{\dagger} \\
(5.0 \text { to } 7.4)\end{array}$ & $\begin{array}{c}2.2 \pm 0.15^{\ddagger} \\
(1.7 \text { to } 2.4)\end{array}$ & $\begin{array}{c}6.5 \pm 0.34 \\
(6.0 \text { to } 7.5)\end{array}$ & $\begin{array}{c}4.8 \pm 0.14 \\
(4.2 \text { to } 5.2)\end{array}$ & $\begin{array}{c}12.6 \pm 0.21^{\ddagger} \\
(11.3 \text { to } \\
14.2)\end{array}$ & $\begin{array}{c}12.16 \pm 0.14^{\sharp} \\
(11.6 \text { to } \\
13.4)\end{array}$ & $\begin{array}{c}3.5 \pm 0.32^{\dagger} \\
(2.2 \text { to } 4.3)\end{array}$ \\
\hline $\mathrm{As}+\mathrm{Ca}$ & $\begin{array}{c}5.8 \pm 0.16^{\dagger} \\
(4.0 \text { to } 7.1)\end{array}$ & $\begin{array}{l}2.7 \pm 0.40^{\dagger} \\
(2.0 \text { to } 3.8)\end{array}$ & $\begin{array}{c}7.3 \pm 0.20 \\
(6.9 \text { to } 7.6)\end{array}$ & $\begin{array}{c}4.8 \pm 0.12 \\
(4.4 \text { to } 5.1)\end{array}$ & $\begin{array}{c}12.3 \pm 0.25 \\
(11.4 \text { to } \\
12.9)\end{array}$ & $\begin{array}{c}16.79 \pm 0.17^{\S} \\
(15.4 \text { to } \\
18.1)\end{array}$ & $\begin{array}{l}3.2 \pm 0.13^{\dagger} \\
(2.7 \text { to } 3.5)\end{array}$ \\
\hline
\end{tabular}

TBARS - thiobarbituric acid reactive substances; ROS - reactive oxygen species measured in $R B C$ in the first minute; GSH and GSSG - reduced and oxidized glutathione; AST and ALT - alanine and aspartate transaminases measured in protein in the first minute; values are expressed as mean $\pm S E(N=6)$; range values are in parenthesis $\dagger$ - significantly different from all other values; $\neq$ and ${ }^{\S}$ - significantly different from unmarked values

selenium, magnesium and calcium to counteract these changes. Our results single out selenium as the most effective protection against arsenic-induced oxidative stress. Selenium is an essential trace element, but at higher doses it is toxic. It is a component of antioxidant enzyme glutathione peroxidase, which together with superoxide dismutase (SOD), catalase (CAT), and vitamin E neutralises ROS. Selenium is known to affect the distribution of many toxic metals. Arsenic has been reported to increase hepatobiliary transport of selenium and facilitate its accumulation in RBCs, and selenite, in turn, to increase biliary excretion of arsenic $(3,22,23)$. Glattre et al. (24) studied the distribution and interaction between arsenic and selenium in rat thyroid. Rats receiving arsenic plus selenium had the same concentrations of both elements as those measured in the groups pre-treated with arsenic or selenium alone. This suggests that both arsenic and selenium accumulate in the thyroid tissue. Post-mortem examination of the thyroid following arsenic exposure showed reduction in size and histological changes in thyroid follicles, whereas only minor changes were observed in selenium or arsenic-plus-selenium treated group. This competition between selenium and toxic metals was contributed to functional proteins and bioligands or active tissue sites or to formation of a reversible compound, metal selenide, which reduced "free" toxic metal ions in the body. Metal selenide may result from interaction between a metal and active selenium (selenide) released from sodium selenite in vivo (18). Badiello et al. (25) suggested that selenium could detoxify metal ions, in addition to its antioxidant action. The authors consider dietary selenium supplementation necessary, preferably in the form of selenomethionine.

Metals and calcium interact at several sites in the body, including cell membrane (through mechanisms that regulate ion transport) (26). Calcium deficiency is known to decrease lead clearance and increases lead absorption, whereas excess calcium only slightly decreases lead clearance and has little effect on lead absorption (27). The mechanism by which calcium interferes with arsenic absorption is not clear. However, several interesting studies suggest that calcium intake rather than calcium status modulates metal absorption in animals (28). Calcium appears to partly inhibit metal absorption via competition for common binding sites on intestinal binding proteins (29).

Relative sensitivity of ALAD to arsenic has been reported earlier (30). In this study, we observed significant depletion of ALAD upon arsenic exposure, perhaps due to the binding of As (III) to the essential -SH group. A decrease in ALAD activity is usually 
related to inadequate diet, particularly deficient in essential metals like selenium (22). In our study, we found a significant recovery in ALAD activity in the arsenic-exposed rats concomitantly receiving selenium, which might be due to preferential binding of selenium to proteins. We did not observe significant changes in GSH concentration. GSH is a tripeptide of three amino acids (glutamic acid, cysteine, and glycine) and is involved in various physiological and metabolic functions. It is a major inter-organ transporter of cysteine, which has a nucleophilic thiol group important for detoxification of electrophilic metabolites. Liver supplies constituents for GSH synthesis in the kidney and intestine. In this study, increased liver and kidney GSH shows antioxidant action of the trace metals. Mishra et al. (30) also reported a significant decline in GSH concentration following arsenic exposure. They also observed a decrease in the GSH:GSSG ratio as an indicator of oxidative stress in the liver and kidney. Administration of calcium and magnesium in our study did not increase blood GSH concentration (Table 2), and GSH depletion may also explain the hepatotoxic effects of arsenic (Table 3). A decrease in GSH and increase in GSSG levels is a sensitive indicator of oxidative stress, and our study clearly shows that arsenic may be the culprit, possibly due to a disruption of oxidant/antioxidant balance. Arsenic-induced TBARS production in our study also supports the oxidative stress hypothesis. As selenium reduced elevated TBARS level, it seems to play a vital role in protecting cells from oxidative stress.

This protective role of selenium is further corroborated by AST and ALT activities, indicative of liver damage. All three trace metals were effective in reducing the level of transaminases in arsenicexposed animals.

Our study has shown that trace metals are valuable against arsenic exposure, selenium in particular if administered at a low level. However, most of the observed changes were only marginal and of much smaller magnitude than the effects of chelation therapy. We therefore recommend that selenium is added to chelation therapy to achieve the best effect.

\section{Acknowledgement}

The authors wish to thank Dr R. Vijayaraghavan, director of the Defence Research and Development Establishment (DRDE), Gwalior for his permission to carry out this study at DRDE.

\section{REFERENCES}

1. Hindmarsh JT. Arsenic, its clinical and environmental significance. J Trace Elem Exp Med 2000;13:165-72.

2. Németi B, Gregus Z. Reduction of arsenate to arsenite in hepatic cytosol. Toxicol Sci 2002;70:4-12.

3. Flora SJS. Arsenic induced oxidative stress and its reversibility following combined administration of $\mathrm{N}$ acetylcysteine and meso 2, 3-dimercaptosuccinic acid in rats. Clin Exp Pharmacol Physiol 1999;26:865-9.

4. Ramos O, Carrizales L, Yáñez L, Meija J, Batres L, Oritz, D. Arsenic increased lipid peroxidation in rat tissues by a mechanism independent of glutathione levels. Environ Health Perspect 1995;103:85-8.

5. Bhuvaneswaran C. The influence of phosphorylation state ratio on energy conservation in mitochondria treated with inorganic arsenate. Biochem Biophys Res Commun 1979;90:1201-6.

6. Rayman MP. The importance of selenium to human health. Lancet 2000;356:233-41.

7. Anderson O, Nielsen JB. Effects of simultaneous low level dietary supplementation with inorganic and organic selenium on whole body, blood and organ levels of toxic metals in mice. Environ Health Perspect 1994;102:321-4.

8. Schrauzer GN. Selenium: Mechanistic aspects of anticarcinogenic action. Biol Trace Elem Res 1992;33:5162.

9. Reed DJ. Glutathione: toxicological implications. Annu Rev Pharmacol Toxicol 1990;30:603-31.

10. Anderson ME. Glutathione and glutathione delivery compounds. Adv Pharmacol 1996;38:65-79.

11. Kaur H, Mishra D, Bhatnagar P, Kaushik P, Flora SJS. Co-administration of $\alpha$-lipoic acid and vitamin $C$ protects liver and brain oxidative stress in mice exposed to arsenic contaminated water. Water Quality Environ Health 2009;1:135-44.

12. Berlin A, Schaller KH. European standardized method for the determination of delta-aminolevulinic acid dehydratase activity in blood. Z Klin Chem Klin Biochem 1974;12:38990.

13. Jollow DJ, Mitchell JR, Zamppaglione Z, Gillette JR. Bromobenzene induced liver necrosis. Protective role of glutathione and evidence for 3,4-bromobenzene oxide as the hepatotoxic metabolites. Pharmacol 1974;11:151-5.

14. Hissin PJ, HilfRA. Fluorometric method for the determination of oxidized and reduced glutathione in tissues. Anal Biochem 1976;74:214-26.

15. Ohkawa H, Ohishi N, Yagi K. Assay for lipid peroxides in animal tissues by thiobarbituric acid reaction. Anal Biochem 1979:95:351-8.

16. Socci DJ, Bjugstad KB, Jones HC, Pattisapu JV, Arendash $\mathrm{GW}$. Evidence that oxidative stress is associated with the pathophysiology of inherited hydrocephalus in the H-Tx rat model. Exp Neurol 1999;155:109-17.

17. Reitman S, Frankel S. A calorimetric method for the determination of serum glutamic oxalacetic and glutamic pyruvic transaminases. Am J Clin Pathol 1957;28:56-63.

18. National Research Council (NRC). Arsenic in Drinking Water. Washington (DC): National Academy Press; 2001.

19. Lindberg AL, Rahman M, Persson LA, Vahter M. The risk of arsenic induced skin lesions in Bangladeshi men and 
women is affected by arsenic metabolism and the age at first exposure. Toxicol Appl Pharmacol 2008;230:9-16.

20. Chen Y, Santella RM, Kibriya MG, Wang Q, Kappil M, Wendy JV, Joseph HG, Ahsan H. Association between arsenic exposure from drinking water and plasma levels of soluble cell adhesion molecules. Environ Health Perspect 2007; $115: 1415-20$

21. Guha Mazumder DN, Ghosal UC, Saha J, Santra A, De BK, Chatterjee A, Dutta S, Angle CR, Ceteno JA. Randomized placebo-controlled trial of 2,3-dimercaptosuccinic acid in therapy of chronic arsenicosis due to drinking arsenic contaminated subsoil water. Clin Toxicol 1998;36:683-90.

22. Flora SJS, Kannan GM, Kumar P. Selenium effects on gallium arsenide induced biochemical and immunotoxicological changes in rats. Chem Biol Interact 1999;122:1-13.

23. Gregus Z, Perjési P, Gyurasics A. Enhancement of selenium excretion in bile by sulfobromophthalein: elucidation of the mechanism. Biochem Pharmacol 1998;56:1391-402.

24. Glattre E, Mravcova A, Lener J, Vobecky M, Egertova E, Mysliveckova M. Study of distribution and interaction of arsenic and selenium in rat thyroid. Biol Trace Elem Res 1995;49:177-86.

25. Badiello R, Feroci G, Fini A. Interaction between trace elements: selenium and cadmium ions. J Trace Elem Med Biol 1996;10:156-62.

26. Pound JG, Long M, Rosen JF. Cellular and molecular toxicity of lead in bone. Environ Health Perspect 1991;91:17-32.

27. Aungst BJ, Fung HL. The effect of dietary calcium on lead absorption, distribution and elimination kinetics in rats. $\mathrm{J}$ Toxicol Health 1985;16:147-59.

28. Barton JC, Conrad ME, Harrison L, Nuby S. Effect of calcium on the absorption and retention of lead. J Lab Clin Med 1978;91:366-76.

29. Kalia K, Flora SJS. Strategies for safe and effective treatment for chronic arsenic and lead poisoning. J Occup Health 2005;47:1-21.

30. Mishra D, Mehta A, Flora SJS. Reversal of arsenic induced hepatic apoptosis with combined administration of DMSA and its analogues in guinea pigs: role of glutathione and linked enzymes. Chem Res Toxicol 2008;21:400-7. 


\title{
Sažetak
}

\section{ZAŠTITNO DJELOVANJE SELENA, KALCIJA I MAGNEZIJA PROTIV OKSIDATIVNOGA STRESA UZROKOVANOG ARSENOM U MUŽJAKA ŠTAKORA}

\begin{abstract}
Anorganski arsen snažan je kancerogen i onečišćivač okoliša. Više od stotinu milijuna ljudi izloženo je povišenim koncentracijama arsena, ponajviše u pitkoj vodi. Esencijalni elementi u tragovima mogu utjecati na toksičnost metala na primarnome mjestu djelovanja te na drugačiji odgovor tijela na toksične metale tako što mijenjaju njihov metabolizam i prijenos. Namjera ovoga istraživanja bila je utvrditi utjecaj istodobne primjene selena, magnezija i kalcija s arsenom na neke biokemijske parametre u krvi te na oksidativni stres. Selen primijenjen istodobno s arsenom najdjelotvornije je smanjio inhibiciju dehidrataze delta-aminolevulinske kiseline (ALAD) u krvi te oksidativni stres u jetri. I djelovanje kalcija i magnezija pokazalo se povoljnim na neke hematološke i biokemijske parametre. Ovi rezultati upućuju na obećavajuću ulogu selena u sprječavanju nastanka znakova i simptoma povezanih s izlaganjem arsenu.
\end{abstract}

KLJUČNE RIJEČI: ALAD, elementi u tragovima, GSH, ROS, TBARS

CORRESPONDING AUTHOR:

Swaran J. S. Flora, MD, PhD

Division of Pharmacology and Toxicology, Defence Research and Development Establishment Jhansi Road, Gwalior-474002, India, Email: sjsflora@hotmail.com or sjsflora@drde.drdo.in 